\title{
Metastatic Clear Cell Sarcoma of Soft Tissue
}

National Cancer Institute

\section{Source}

National Cancer Institute. Metastatic Clear Cell Sarcoma of Soft Tissue. NCI Thesaurus. Code C161585.

A clear cell sarcoma of soft tissue that has spread from the orig inal site of growth to other anatomic sites. 